\title{
EHMTI-0261. Idiopathic intracranial hypertension presenting as acute onset bilateral visual loss
}

\author{
R Handa*, RS Jain, K Nagpal, S Prakash, I Bhana, MS Sisodiya, PK Gupta \\ From 4th European Headache and Migraine Trust International Congress: EHMTIC 2014 \\ Copenhagen, Denmark. 18-21 September 2014
}

\section{Introduction}

Idiopathic intracranial hypertension (IIH) is a disorder of elevated cerebrospinal fluid pressure of unknown cause. Visual acuity usually remains normal except when the condition is long standing and severe.

\section{Aims}

This case highlights occurrence of acute onset visual loss as a rare presentation of IIH.

\section{Case report}

A 27-years-old obese female, presented with 15 days history of acute onset holocranial throbbing headache and eight days history of acute onset rapidly progressive visual loss in both eyes. Neurological examination revealed bilateral papilloedema with visual acuity $6 / 60$ in right eye and $1 / 60$ in left eye with no other neurological deficit. Contrast enhanced MRI brain was suggestive of IIH and CT venography was normal. CSF manometry showed $520 \mathrm{~mm}$ of CSF pressure with normal protein and cellular response. Thus, a final diagnosis of definite IIH was made. Acetazolamide $250 \mathrm{mg}$ thrice a day was started with which she had significant improvement in headache and visual acuity over next 2 weeks and visual acuity was recorded as 6/18 in both eyes at two weeks follow up.

\section{Conclusion}

IIH should always be considered as a possible diagnosis in a patient with headache and papilloedema with no other signs of focal neurological deficits. Although uncommon, acute onset visual loss in IIH can be presenting feature in some patients.
No conflict of interest.

Published: 18 September 2014

doi:10.1186/1129-2377-15-S1-C21

Cite this article as: Handa et al.: EHMTI-0261. Idiopathic intracranial hypertension presenting as acute onset bilateral visual loss. The Journal of Headache and Pain 2014 15(Suppl 1):C21.
Submit your manuscript to a SpringerOpen ${ }^{\circ}$ journal and benefit from:

- Convenient online submission

- Rigorous peer review

- Immediate publication on acceptance

- Open access: articles freely available online

- High visibility within the field

- Retaining the copyright to your article
(C) 2014 Handa et al; licensee Springer. This is an Open Access article distributed under the terms of the Creative Commons Attribution License (http://creativecommons.org/licenses/by/2.0), which permits unrestricted use, distribution, and reproduction in any medium, provided the original work is properly cited. 


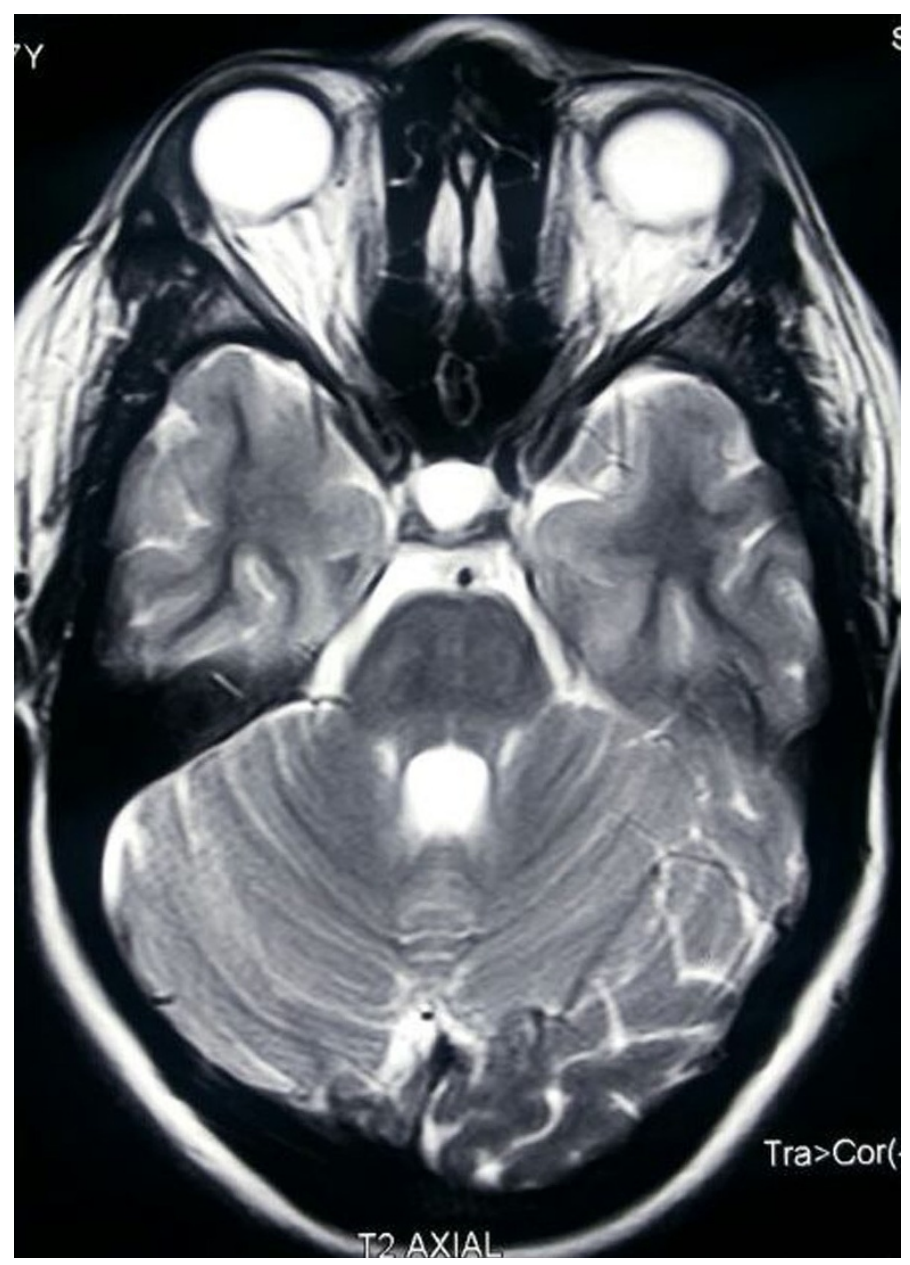

Figure $1 \mathrm{MRI}$ Brain T2W axial image showing empty sella and flattening of posterior aspect of globe.
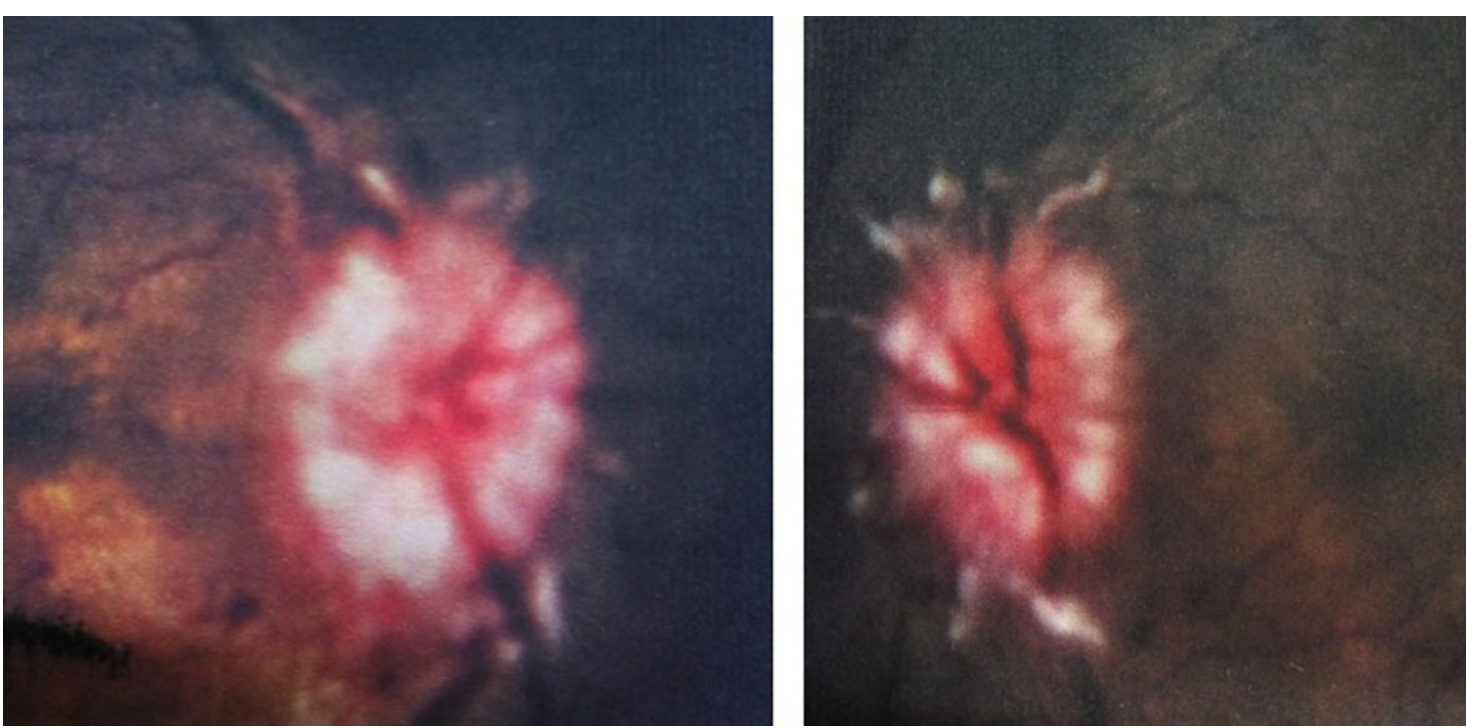

Figure 2 Photograph of fundi showing bilateral papilloedema 